\title{
Biosynthesis of the dideoxysugar component of jadomycin B: genes in the jad cluster of Streptomyces venezuelae ISP5230 for L-digitoxose assembly and transfer to the angucycline aglycone
}

\author{
Liru Wang $^{1}$, Robert L. White ${ }^{2}$ and Leo C. Vining ${ }^{1}$ \\ Author for correspondence: Leo C. Vining. Tel: +1 902494 2040. Fax: +1 9024943736. \\ e-mail: leo.vining@dal.ca
}

1 Department of Biology, Dalhousie University, Halifax, Nova Scotia, Canada B3H 4J1

2 Department of Chemistry, Dalhousie University, Halifax, Nova Scotia, Canada B3H 4J3
Eight additional genes, jadX, O, P, Q, S, T, U and $V$, in the jad cluster of Streptomyces venezuelae ISP5230, were located immediately downstream of jad $N$ by chromosome walking. Sequence analyses and comparisons implicated them in biosynthesis of the 2,6-dideoxysugar in jadomycin B. The genes were cloned in Escherichia coli, inactivated by inserting an apramycin resistance cassette with a promoter driving transcription of downstream genes, and transferred into Streptomyces venezuelae by intergeneric conjugation. Analysis by HPLC and NMR of intermediates accumulated by cultures of the insertionally inactivated Streptomyces venezuelae mutants indicated that jadO, $P, Q, S, T, U$ and $V$ mediate formation of the dideoxysugar moiety of jadomycin $B$ and its attachment to the aglycone. Based on these results and sequence similarities to genes described in other species producing deoxysugar derivatives, a biosynthetic pathway is proposed in which the jadQ product (glucose-1-phosphate nucleotidyltransferase) activates glucose to its nucleotide diphosphate (NDP) derivative, and the jadT product (a 4,6dehydratase) converts this to NDP-4-keto-6-deoxy-D-glucose. An NDP-hexose 2,3-dehydratase and an oxidoreductase, encoded by jadO and jadP, respectively, catalyse ensuing reactions that produce an NDP-2,6-dideoxy-Dthreo-4-hexulose. The product of jadU (NDP-4-keto-2,6-dideoxy-5-epimerase) converts this intermediate to its L-erythro form and the jadV product (NDP-4keto-2,6-dideoxyhexose 4-ketoreductase) reduces the keto group of the NDP-4hexulose to give an activated form of the L-digitoxose moiety in jadomycin B. Finally, a glycosyltransferase encoded by jadS transfers the activated sugar to jadomycin aglycone. The function of jadX is unclear; the gene is not essential for jadomycin B biosynthesis, but its presence ensures complete conversion of the aglycone to the glycoside. The deduced amino acid sequence of a $612 \mathrm{bp}$ ORF (jad $R^{*}$ ) downstream of the dideoxysugar biosynthesis genes resembles many TetR-family transcriptional regulator sequences.

Keywords: antibiotic, gene disruption, polyketide glycoside

\section{INTRODUCTION}

Polyketide intermediates generated by sequential condensation of activated low-molecular-mass carboxylic acid metabolites catalysed by polyketide synthases
(PKSs) are converted into many types of naturally occurring aromatic and macrocyclic ester structures. Among compounds of this type produced as secondary metabolites by actinomycetes is the antibiotic jadomycin B, discovered in Streptomyces venezuelae ISP5230. The

Abbreviations: Am, apramycin; NDP, nucleotide diphosphate; PKS, polyketide synthase.

The GenBank accession number for the sequence reported in this paper is AY026363. 


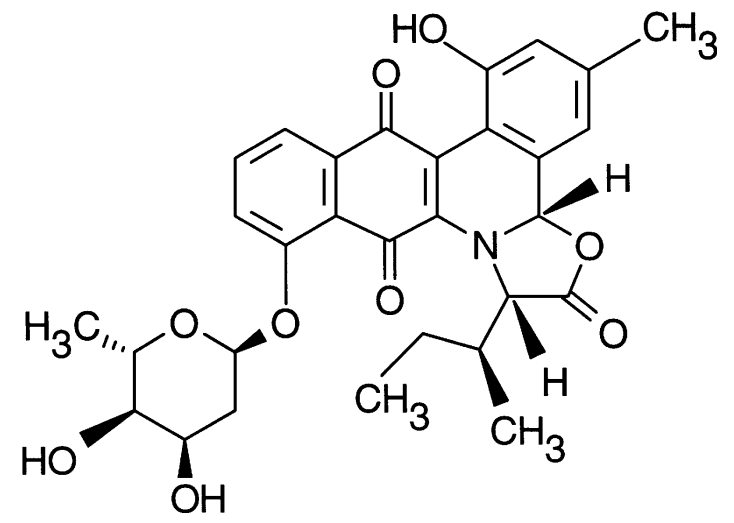

Fig. 1. Structure of jadomycin B.

deduced chemical structure (Ayer et al., 1991; Doull et al., 1993) and the pattern of labelling by $\left[{ }^{13} \mathrm{C}\right]$ acetate (Crowell, 1993) indicate that jadomycin B contains polyketide aglycone and a 2,6-dideoxysugar moiety. A recent X-ray diffraction analysis of crystalline jadomycin $\mathrm{B}$ has refined stereochemical features of the structure (Fig. 1; T. S. Cameron, R. L. White, L. Wang $\&$ L. C. Vining, unpublished) and established that the glycosidic moiety is L-digitoxose. Molecular genetic evidence has established that the aglycone is biosynthesized from a decapolyketide generated by an iterative type-II PKS complex encoded by a chromosomal gene cluster (Han et al., 1994; Kulowski et al., 1999; Wang et al., 2001).

Many polyketide-derived secondary metabolites exhibit biological activity and are important pharmaceutical agents. The medical applications of these compounds have fostered programmes to obtain new structures with enhanced or modified properties. Novel metabolites can be generated by interchanging secondary metabolic biosynthesis genes among a variety of micro-organisms, or by creating hybrid genes that direct the synthesis of unique and hitherto unavailable structures. Since Hopwood \& Sherman (1990) reviewed polyketide antibiotic synthesis with a focus on PKS genes, there has been substantial progress in recombining genes to construct novel polyketide aglycones (Hutchinson 1999; McDaniel et al., 1999; David et al., 1998; Shen et al., 1999); recent extensions of this approach to include deoxysugar biosynthesis genes expand opportunities to genetically engineer new microbial metabolites with medical applications (Olano et al., 1999; Gaisser et al., 2000).

Deoxysugars are found in nature as constituents of glycoproteins, bacterial cell walls and glycosidic secondary metabolites. The 2,6- and 4,6-dideoxyhexoses, in particular, are present in a broad of range of bioactive compounds. The precise function of the carbohydrate moiety in most glycosylated metabolites has not been elucidated, but the presence of a deoxysugar seems to alter responses at the interface between a compound and its surroundings: daunosamine in daunorubicin and doxorubicin confers antineoplastic activity (Krugel et al., 1993), glycosylation detoxifies oleandomycin during its biosynthesis (Quiros et al., 1998) and oligosaccharide moieties stabilize antibiotic binding in the minor groove of DNA (Walker et al., 1990). The existence of a large variety of deoxysugars suggests selection for diversity in their biosynthesis, and an influence of structural differences on the properties of the final product. However, contributions to mechanisms of action are still poorly understood, and except for the 3,6-dideoxysugar ascarylose (Liu \& Thorson, 1994; Kirshning et al., 1997), knowledge of biosynthetic pathways is also incomplete. In the route to jadomycin B, many genes associated with assembly of the aglycone have been identified, but knowledge of the genes responsible for synthesizing and attaching the sugar moiety is limited to detection in the Streptomyces venezuelae jad cluster of a partial ORF with sequence similarity to dideoxysugar biosynthesis genes (Wang et al., 2001). Here we report the discovery by chromosomal walking of a group of adjacent genes, jadXOPQSTUV, occupying approximately $9 \mathrm{~kb}$ of the chromosome downstream of the jad PKS cluster. We show by disruptions that the genes are required to form or attach the dideoxysugar in jadomycin B and propose from sequence comparisons with dideoxysugar biosynthesis genes in other organisms that jadXOPQSTUV encodes the pathway synthesizing the $\mathrm{L}$-digitoxose component of the antibiotic.

\section{METHODS}

Bacterial strains, plasmids and vectors. These are listed in Table 1.

Culture conditions. Escherichia coli strains used for plasmid isolation and $\lambda$ phage propagation were grown as described by Sambrook et al. (1989). Jadomycin B was produced in galactose-isoleucine medium (Doull et al., 1993), but with isoleucine doubled to $7 \cdot 8 \mathrm{~g} \mathrm{l}^{-1}$ (giving Gal2I medium). Recombinant $E$. coli $\mathrm{DH} 5 \alpha$ strains were grown in $\mathrm{LB}$ medium containing appropriate antibiotics (Sambrook et al., 1989). Strains of Streptomyces venezuelae from which genomic DNA was isolated were grown in MYM medium (Stuttard, 1982) at $30{ }^{\circ} \mathrm{C}$ for $24 \mathrm{~h}$ on a rotary shaker $(220$ r.p.m.). To assess promoter activity by measuring catechol 2,3-dioxygenase in Streptomyces venezuelae cell extracts, strains transformed with pXE4 or pXE4:: $\mathrm{Am}^{\mathrm{R}}$ were grown for 2 days at $30^{\circ} \mathrm{C}$ on a rotary shaker (220 r.p.m.) in either MYM or Gal2I culture medium.

DNA manipulation and transformation. Bacteriophage $\lambda$ DNA was purified as described previously (Wang et al., 2001). Plasmid DNA was isolated from E. coli by the alkaline lysis method (Sambrook et al., 1989). Streptomycete genomic DNA was isolated as described by Hopwood et al. (1985). T4 DNA ligase and restriction enzymes were used as recommended by the suppliers. Competent E. coli cells were prepared and transformed by the procedures of Sambrook et al. (1989). In transformations of Streptomyces venezuelae by the protoplasting procedure, the methods of Kieser et al. (2000) for preparing and transforming protoplasts were modified as follows: spores were grown in MYME medium (Yang et al., 1996) at $30^{\circ} \mathrm{C}$ on a rotary shaker (220 r.p.m.) for 24 h, 
Table 1. Bacterial strains, plasmids and phages

\begin{tabular}{|c|c|c|}
\hline $\begin{array}{l}\text { Strain, plasmid } \\
\text { or phage }\end{array}$ & Genotype/phenotype & Source/reference \\
\hline \multicolumn{3}{|l|}{$\begin{array}{l}\text { Streptomyces } \\
\text { venezuelae }\end{array}$} \\
\hline ISP5230 & Wild-type, jadomycin B producer & Stuttard (1982) \\
\hline VS1079/1080 & ISP5230 with jadO disrupted by $\mathrm{Am}^{\mathrm{R}}$ gene in opposite orientation & This study \\
\hline VS1081/1082 & ISP5230 with jadP disrupted by $\mathrm{Am}^{\mathrm{R}}$ gene in opposite orientation & This study \\
\hline VS1083/1084 & ISP5230 with $j a d Q$ disrupted by $\mathrm{Am}^{\mathrm{R}}$ gene in opposite orientation & This study \\
\hline VS1085/1086 & ISP5230 with jadX disrupted by $\mathrm{Am}^{\mathrm{R}}$ gene in opposite orientation & This study \\
\hline VS1087/1088 & ISP5230 with jadS disrupted by $\mathrm{Am}^{\mathrm{R}}$ gene in opposite orientation & This study \\
\hline VS1089/1090 & ISP5230 with jadT disrupted by $\mathrm{Am}^{\mathrm{R}}$ gene in opposite orientation & This study \\
\hline VS1091/1092 & ISP5230 with jadU disrupted by $\mathrm{Am}^{\mathrm{R}}$ gene in opposite orientation & This study \\
\hline VS1093/1094 & ISP5230 with $j a d V$ disrupted by $\mathrm{Am}^{\mathrm{R}}$ gene in opposite orientation & This study \\
\hline \multicolumn{3}{|l|}{ Escherichia coli } \\
\hline DH5 $\alpha \mathrm{F}^{\prime} \mathrm{IQ}$ & 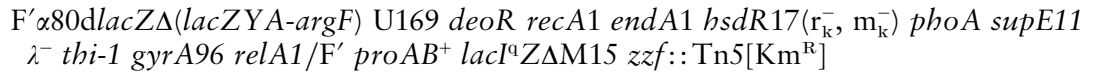 & Gibco-BRL \\
\hline ET 12567 & $d a m^{-} d c m^{-} h s d M^{-}$ & MacNeil et al. (1992) \\
\hline ET 12567(pUZ8002) & ET12567 containing pUZ8002 & M. Paget, John Innes \\
\hline \multicolumn{3}{|l|}{ Plasmid } \\
\hline pBluescript II & $\begin{array}{l}\text { Phagemid derivative of pUC18, } \mathrm{SK}(+) \text { and } \mathrm{KS}(+), \mathrm{f} 1 \text { ori, and primer-binding sites } \\
\text { for } \mathrm{T} 3 \text { and } \mathrm{T} 7\end{array}$ & Stratagene \\
\hline pHJL400 & tsr amp lac $Z$, bifunctional & $\begin{array}{l}\text { Larson \& } \\
\text { Hershberger (1986) }\end{array}$ \\
\hline pUC18 & ori lacZ amp & \\
\hline pJV225 & pBluescript II SK $(+)$ containing $\mathrm{Am}^{\mathrm{R}}$ gene flanked by multiple cloning sites & Chang et al. (2001) \\
\hline pJV326 & pHJL400 with $0.76 \mathrm{~kb}$ PstI insert containing oriT, bifunctional & He et al. (2001) \\
\hline pJV401 & pBluescript II SK(+) with $6.6 \mathrm{~kb}$ XhoI insert from phage LW3 & Wang et al. (2001) \\
\hline pJV410 & $\begin{array}{l}\text { pUC18 with } 6.0 \mathrm{~kb} \text { PstI-BamHI insert from pJV401 containing jadMNXO and } \\
\text { downstream genes }\end{array}$ & This study \\
\hline pJV411 & $\begin{array}{l}\text { pBluescript II SK }(+) \text { with } 3.5 \mathrm{~kb} K p n \mathrm{I}-\mathrm{Xhol} \text { fragment from pJV401 containing } 5^{\prime} \\
\text { region of } j a d \mathrm{O} \text { and downstream genes }\end{array}$ & This study \\
\hline $\mathrm{pJV} 413 \mathrm{~A} / \mathrm{B}$ & $\begin{array}{l}\text { pUC18 with } 6.0 \mathrm{~kb} \text { XhoI-Bam HI fragment containing } 1.6 \mathrm{~kb} \mathrm{Am}^{\mathrm{R}} \text { gene in EcoRV } \\
\text { site; pJV413A/B in opposite orientation }\end{array}$ & This study \\
\hline $\mathrm{pJV} 414 \mathrm{~A} / \mathrm{B}$ & $\begin{array}{l}\text { pUC18 with } 6.0 \mathrm{~kb} \text { XhoI-Bam HI fragment containing } 1.6 \mathrm{~kb} \mathrm{Am}^{\mathrm{R}} \text { gene in } \mathrm{KpnI} \\
\text { site; pJV414A/B in opposite orientation }\end{array}$ & This study \\
\hline $\mathrm{pJV} 415 \mathrm{~A} / \mathrm{B}$ & pJV326 with $7 \cdot 6 \mathrm{~kb}$ EcoRI-XbaI fragment subcloned from pJV414A/B & This study \\
\hline $\mathrm{pJV} 416 \mathrm{~A} / \mathrm{B}$ & $\begin{array}{l}\text { pBluescript II SK(+) with } 3.5 \mathrm{~kb} \mathrm{KpnI-XhoI} \mathrm{fragment} \mathrm{containing} 1.6 \mathrm{~kb} \mathrm{Am}^{\mathrm{R}} \text { gene } \\
\text { in blunted BstEII site; pJV416A/B in opposite orientation }\end{array}$ & This study \\
\hline pJV417A/B & $\begin{array}{l}\text { pBluescript II SK(+) with } 2.2 \mathrm{~kb} \text { Not } \mathrm{I}-\mathrm{X} \text { hoI fragment containing } 1.6 \mathrm{~kb} \mathrm{Am}^{\mathrm{R}} \text { gene } \\
\text { in blunted MaeII site; pJV417A/B in opposite orientation }\end{array}$ & This study \\
\hline $\mathrm{pJV} 418 \mathrm{~A} / \mathrm{B}$ & $\begin{array}{l}\text { pUC18 with } 2 \cdot 0 \mathrm{~kb} \text { Bam HI fragment containing } 1 \cdot 6 \mathrm{~kb} \mathrm{Am}^{\mathrm{R}} \text { gene in } \mathrm{NruI} \\
\text { site; pJV418A/B in opposite orientation }\end{array}$ & This study \\
\hline $\mathrm{pJV} 419 \mathrm{~A} / \mathrm{B}$ & $\begin{array}{l}\text { pUC18 with } 2.3 \mathrm{~kb} S t u \mathrm{I}-K p n \mathrm{I} \text { fragment containing } 1.6 \mathrm{~kb} \mathrm{Am}^{\mathrm{R}} \text { gene in blunted } \\
\text { BamHI site; pJV419A/B in opposite orientation }\end{array}$ & This study \\
\hline $\mathrm{pJV} 420 \mathrm{~A} / \mathrm{B}$ & $\begin{array}{l}\text { pUC18 with } 2.9 \mathrm{~kb} N r u \mathrm{I} \text { fragment containing } 1.6 \mathrm{~kb} \mathrm{Am}^{\mathrm{R}} \text { gene in blunted BstEII } \\
\text { site; pJV420A/B in opposite orientation }\end{array}$ & This study \\
\hline $\mathrm{pJV} 421 \mathrm{~A} / \mathrm{B}$ & $\begin{array}{l}\text { pUC18 with } 3.8 \mathrm{~kb} \text { Bam } \mathrm{HI} \text { fragment containing } 1.6 \mathrm{~kb} \mathrm{Am}^{\mathrm{R}} \text { gene in } \mathrm{NruI} \\
\text { site; pJV417A/B in opposite orientation }\end{array}$ & This study \\
\hline pJV423 & pBluescript II SK(+) with $2 \cdot 0 \mathrm{~kb} \mathrm{BamHI}$ fragment from LW12 & This study \\
\hline pJV424 & pBluescript II SK $(+)$ with $0.56 \mathrm{~kb} \mathrm{NruI-BamHI}$ fragment from pJV423 & This study \\
\hline pJV425 & $\begin{array}{l}\text { pUC18 carrying in its } S m a \mathrm{I} \text { site a } 5 \cdot 6 \mathrm{~kb} \text { StuI fragment containing jadS and } \\
\text { downstream genes subcloned from } \lambda \mathrm{LW} 18\end{array}$ & This study \\
\hline pJV426 & $\begin{array}{l}\text { pBluescript II SK }(+) \text { with } 4 \cdot 2 \mathrm{~kb} \mathrm{NruI-BamHI} \text { fragment containing genes } \\
\text { downstream of } j a d S\end{array}$ & This study \\
\hline pJV427 & pJV326 with $4.2 \mathrm{~kb} \mathrm{NruI-BamHI}$ fragment containing genes downstream of $j a d S$ & This study \\
\hline \multicolumn{3}{|l|}{ Phage } \\
\hline$\lambda \mathrm{LW} 3$ & $\lambda$ GEM-11 with $11.5 \mathrm{~kb}$ insert of Streptomyces venezuelae DNA & Wang et al. (2001) \\
\hline$\lambda \mathrm{LW} 12$ & $\lambda$ GEM-11 with $9.5 \mathrm{~kb}$ insert of Streptomyces venezuelae DNA & This study \\
\hline$\lambda \mathrm{LW} 18$ & $\lambda$ GEM-11 with $15.5 \mathrm{~kb}$ insert of Streptomyces venezuelae DNA & This study \\
\hline$\lambda$ gene bank & $\lambda$ GEM-11 with 9.0-23.0 kb inserts of Streptomyces venezuelae genomic DNA & Facey (1994) \\
\hline
\end{tabular}




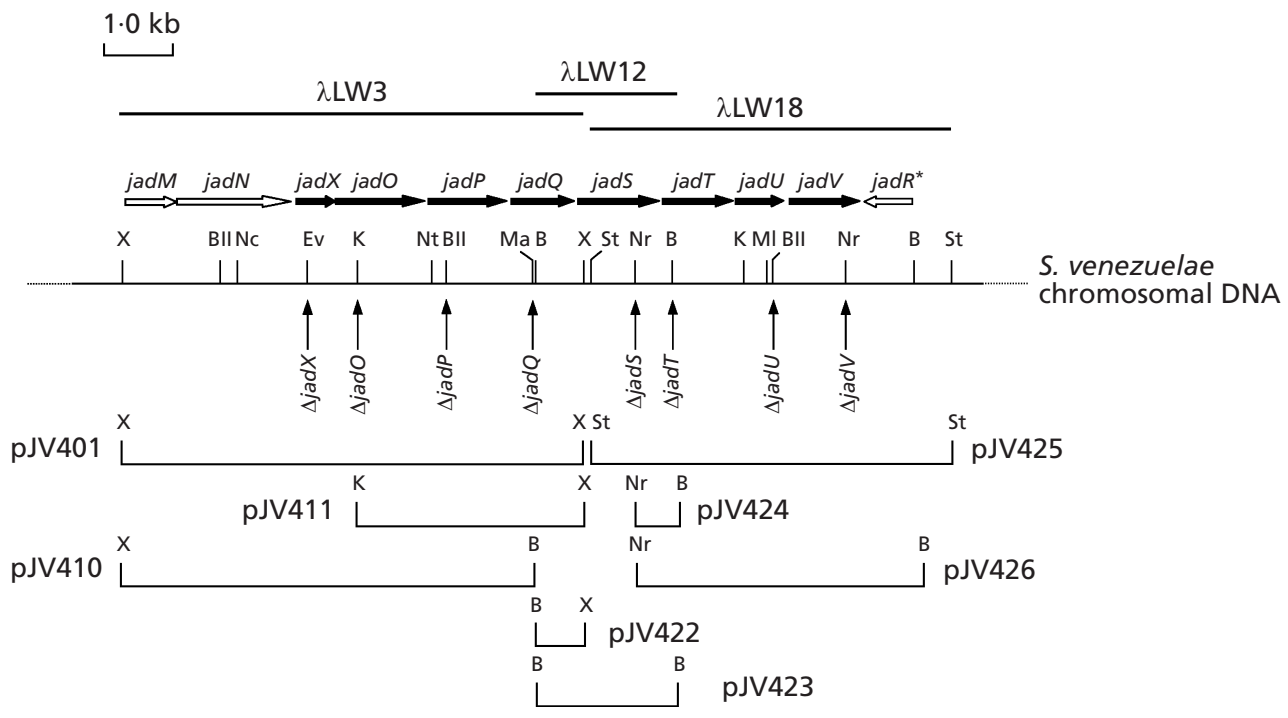

Fig. 2. Restriction map of the $13 \mathrm{~kb}$ region of Streptomyces venezuelae ISP5230 genomic DNA subcloned in the three recombinant $\lambda$ vectors LW3, LW12 and LW18. Arrows above the restriction map show the locations and orientations of the ORFs in the jad cluster. The filled arrows represent genes involved in biosynthesis or attachment of the deoxysugar in jadomycin B. Unfilled arrows represent jad cluster genes flanking the deoxysugar pathway genes. Vertical arrows below the restriction map point to sites where an $\mathrm{Am}^{\mathrm{R}}$ cassette was inserted in each orientation to disrupt a deoxysugar pathway gene. Restriction sites defining the inserts in plasmids pJV401, pJV410, pJV411, pJV422, pJV423, pJV424, pJV425 and pJV426/pJV427 are aligned below the map. Abbreviations: B, BamHI; BII, BstEII; Ev, EcoRV; K, Kpnl; Ma, Maell; MI, Mlul; Nc, Ncol; Nr, Nrul; Nt, Notl; St, Stul; X, Xhol.

mycelium was regenerated on M2YE mannitol/maltose agar (Yang et al., 1996) and transformants were selected by overlaying with soft nutrient agar containing $50 \mu \mathrm{g}$ thiostrepton or apramycin $(\mathrm{Am}) \mathrm{ml}^{-1}$. For conjugal transfer of plasmids from E. coli to streptomycetes, the protocol of Mazodier et al. (1989) was followed.

Cloning and sequencing deoxysugar genes. The $3.5 \mathrm{~kb}$ KpnI-XhoI fragment of the pJV401 insert (Wang et al., 2001) was subcloned in pBluescript II SK ( + ) to give pJV411 (Fig. 2). Nested overlapping deletions were introduced into the pJV411 insert with an ExoIII/SI deletion kit (MBI Fermentas) and the cloned DNA was sequenced by the dideoxynucleotide chaintermination method. A $0.6 \mathrm{~kb}$ Bam HI-XhoI fragment from the XhoI end of pJV411 (see Fig. 2) was subcloned as pJV422 and used to probe a genomic library prepared in $\lambda$ GEM-11 from a partial Sau3AI digest of Streptomyces venezuelae ISP5230 (Facey, 1994). A library fragment ( $\lambda$ LW12) that hybridized with the probe was cloned in pBluescript II SK $(+)$ as pJV423 (see Fig. 2). For further chromosome walking, a $0.6 \mathrm{~kb}$ NruI-BamHI fragment of pJV423, subcloned in pJV424, was labelled with $\left[{ }^{32} \mathrm{P}\right] \mathrm{dCTP}$ and used to probe the Streptomyces venezuelae genomic library. A library fragment (LW18) that hybridized with the probe was recloned as a $5.6 \mathrm{~kb}$ StuI fragment in pUC18, giving pJV425. The inserts in pJV423 and pJV425, sequenced as described for pJV411, contained an overlapping region; the pJV423 sequence also overlapped pJV401 (see Fig. 2).

Sequence analysis. The sequenced pJV411, pJV423 and pJV425 inserts were examined with ORF Finder (NCBI) and FramePlot 2.3 (Ishikawa \& Hotta, 1999) to detect ORFs. BLASTX was used with individual ORF sequences and BLASTP with their translated sequences, to query GenBank. Sequences were aligned and their relatedness was assessed with CLUSTAL w (Thompson et al., 1994).
Construction of pXE4:: $\mathrm{Am}^{\mathrm{R}}$. The $\mathrm{Am}^{\mathrm{R}}$ gene was excised from pJV225 (Chang et al., 2001) as a HindIII fragment and ligated into the HindIII site of pXE4 (Ingram et al., 1989) with the same transcriptional orientation as $x y l E$. The pXE4:: Am ${ }^{\mathrm{R}}$ construct and a pXE4 control plasmid were passaged through E. coli ET12567 before being used to transform protoplasts of Streptomyces venezuelae ISP5230.

Gene disruption. Plasmid inserts containing jadX, $O, P, Q, S$, $T, U$ and $V$ were mapped with restriction enzymes and a central site in each was targeted for insertional inactivation. Thus to disrupt jadO, pJV410 was linearized with KpnI. The linear fragment was blunt-ended by treatment with SI nuclease and ligated with the $1.6 \mathrm{~kb}$ EcoRV cassette containing apr retrieved from pJV225. The constructs (pJV414A/B) contained apr in opposite transcriptional orientations. Fragments containing the disrupted genes were retrieved from an agarose gel and ligated with the oriT-containing vector pJV326, giving pJV415A/B. To avoid restriction in Streptomyces venezuelae ISP5230, the plasmid constructs were passaged through the DNA methylation-deficient E. coli strain ET12567(pUZ8002) before being transferred from $E$. coli to Streptomyces venezuelae ISP5230 by intergeneric conjugation using the procedure described by Flett et al. (1997) and Mazodier et al. (1989). Single colonies of the transconjugant strains VS1079/ 1080, each resistant to apramycin but sensitive to thiostrepton, were selected. Using similar methods, $j a d X, j a d P, j a d Q, j a d S$, $j a d T, j a d U$ and $j a d V$ cloned in either pBluescript II SK $(+)$ or pUC18 were disrupted by inserting the $\mathrm{Am}^{\mathrm{R}}$ cassette in alternative directions at the EcoRV, BstEII, MaeII, NruI, BamHI, BstEII and NruI sites, respectively (see Fig. 2), to give pJV413A/B, pJV416A/B, pJV417A/B, pJV418A/B, $\mathrm{pJV} 419 \mathrm{~A} / \mathrm{B}, \mathrm{pJV} 420 \mathrm{~A} / \mathrm{B}$ and $\mathrm{pJV} 421 \mathrm{~A} / \mathrm{B}$, respectively. In each pair of plasmids, the member designated A carried the $\mathrm{Am}^{\mathrm{R}}$ gene in the opposite transcriptional orientation to the 
gene disrupted. The inserts were excised and ligated to pJV326, then passaged through E. coli ET12567(pUZ8002) and transferred conjugally from E. coli to Streptomyces venezuelae ISP5230 as in the procedure above for jadO disruption. Transconjugant strains VS1081/1082, VS1083/ 1084, VS1085/1086, VS1087/1088, VS1089/1090, VS1091/ 1092 and VS1093/1094, each of which was resistant to apramycin but sensitive to thiostrepton, were selected. The first member of each pair contained the A series of plasmids $\left(A m^{\mathrm{R}}\right.$ gene in opposite orientation to the disrupted gene).

Construction of merodiploids for gene complementation. The $3.6 \mathrm{~kb} \mathrm{BamHI}$ fragment containing $j a d T, U, V$ and $R *$ was ligated to the $\mathrm{BamHI}$ end of the fragment cloned in pBluescript II as pJV424 to give pJV426. The $4 \cdot 2 \mathrm{~kb} \mathrm{NruI-BamHI}$ insert in pJV426 was retrieved by EcoRI-HindIII digestion, end-filled by incubation with the Klenow fragment of DNA polymerase I and inserted into EcoRI-digested and end-filled pJV326. The plasmid obtained (pJV427) was passaged through ET12567 (pUZ8002) and transferred conjugally into the following Streptomyces venezuelae strains: VS1087 (jadS disrupted), VS1089 (jadT disrupted), VS1091 (jadU disrupted) and VS1093 (jadV disrupted).

Hybridization. Procedures described by Hopwood et al. (1985) and Sambrook et al. (1989) were used to screen a Streptomyces venezuelae ISP5230 genomic DNA library in $\lambda$ GEM-11 (Facey, 1994). Phage hybridizations and Southern hybridizations were performed as described by Wang et al. (2001).

Jadomycin production and analysis. Cultures of Streptomyces venezuelae were analysed for jadomycin production by HPLC; the retention times for jadomycin $\mathrm{B}$ and its aglycone were $7 \cdot 5$ and $8.4 \mathrm{~min}$, respectively (Wang et al. (2001). Ethyl acetate extracts of cultures from strains with disrupted genes were evaporated in vacuo and the residues (20-25 mg), redissolved in chloroform, were fractionated by flash chromatography on silica gel H (Merck); green-coloured eluate fractions, which gave an HPLC peak at $8.4 \mathrm{~min}$, contained the aglycone. They were evaporated in vacuo and the residues $(1 \cdot 0-1 \cdot 1 \mathrm{mg})$, taken up in $\mathrm{CDCl}_{3}$, were examined with a Bruker AMX 400 spectrometer at $400 \cdot 1$ and $100 \cdot 6 \mathrm{MHz}$ to obtain ${ }^{1} \mathrm{H}$ and ${ }^{13} \mathrm{C}$ NMR spectra, respectively.

Measurement of catechol 2,3-dioxygenase activity. Transformants selected on MYM agar supplemented with thiostrepton or apramycin were patched on the appropriate medium and incubated at $30^{\circ} \mathrm{C}$ for $2-3$ days. The patches were then sprayed with $0.5 \mathrm{M}$ aqueous catechol (Zukowski et al., 1983; Ingram et al., 1989) and examined for the formation of a yellow product. To measure catechol 2,3-dioxygenase activity quantitatively, transformants were grown, along with controls, in shaken cultures. Enzyme activity in sonicated cell extracts was measured colorimetrically by the methods of Ingram et al. (1989) and Kieser et al. (2000). Protein in cell extracts was measured with the bicinchoninic acid reagent (Pierce).

\section{RESULTS}

\section{Sequence of jad genes downstream of jadN}

In a previous investigation, Wang et al. (2001) obtained a DNA fragment from a genomic library of Streptomyces venezuelae ISP5230 and cloned it in $\lambda \mathrm{LW} 3$. The insert from LW3 was subcloned as a $7.0 \mathrm{~kb} X h o \mathrm{I}$ fragment in pJV401. Sequencing a $3.4 \mathrm{~kb}$ XhoI-KpnI segment at the left-hand end of the pJV401 insert (see
Fig. 2) identified ORFs for jadM, encoding a phosphopantetheinyl transferase, and jadN, encoding an acylcoenzyme A decarboxylase, both associated with biosynthesis of jadomycin aglycone. In addition, the sequence included an unidentified gene $(j a d X)$ and a partial gene $(j a d O)$ potentially involved in biosynthesis of the sugar component in jadomycin $\mathrm{B}$. The sequence between $j a d N$ and jaxX contained an in-frame TGA 268 bp distant from the start of $j a d X$ and assumed to be a stop codon; however, subsequent FramePlot analyses showed that transcription of $j a d N$ did not terminate until it reached a second in-frame TGA only 22 bp away from jadX. Thus the 268 bp separation between jadN and jaxX reported previously (Wang et al., 2001) is now considered incorrect. The remainder of jadO was obtained by subcloning (as pJV411) the $3.6 \mathrm{~kb} \mathrm{KpnI-}$ XhoI segment from the right-hand end of the pJV401 insert. In addition, adjacent jad genes were obtained from the genomic library by chromosome walking. Probing with a BamHI-XhoI segment of DNA subcloned in pJV422 from the right-hand end of pJV411 (see Fig. 2) identified $\lambda \mathrm{LW} 12$ and the overlapping $\lambda$ LW18. The LW12 insert was recloned as a BamHI fragment in pJV423 and the LW18 insert as a StuI fragment in pJV425. Sequencing and analysis of the inserts in pJV411, JV423 and pJV425 detected nine complete ORFs ( $j a d X, O, P, Q, S, T, U, V$ and $R^{*}$ : see Fig. 2). Their properties are summarized in Table 2. Eight of the ORFs $(j a d X-V)$ were transcribed in the same direction. They were followed by the oppositely oriented jadR*, encoding 204 aa. The $j a d V$ and $j a d R^{*}$ stop codons were separated by $16 \mathrm{bp}$.

\section{Functions of $j a d X, O, P, Q, S, T, U, V$ and $R^{*}$}

jadX. A BLASTP search showed the sequence of the jadX product to be $26 \%$ identical to that of MmyY (GenBank accession no. AJ276673), a protein of undetermined function encoded by a gene in the methylenomycin biosynthesis cluster located in the large linear plasmid SCP1 of Streptomyces coelicolor A3(2). The jadX product also showed $24 \%$ sequence identity to the product of ORF5 (GenBank AF127374) from Streptomyces lavendulae, but the probability of chance identity is high and the function of ORF5 is uncertain.

jado. In BLASTX searches with its deduced amino acid sequence, jadO showed similarity to genes for many nucleotide diphosphate (NDP)-hexose 2,3-dehydratases. The closest match $(72 \%$ identity) was with UrdS, involved in forming the D-olivose and L-rhodinose moieties of urdamycin, but JadO also resembled dTDP4-keto-6-deoxy-L-hexose 2,3-dehydratase encoded by aveBVI of 'Streptomyces avermitilis' (59\% identical aa), D-olivose, D-oliose and D-mycarose 2,3-dehydratases $(\mathrm{MtmV})$ of 'Streptomyces argillaceus' (51\% identical aa) and the products of lanS in 'Streptomyces cyanogenus' (68\% identity), ORF10 in Streptomyces violaceoruber (47\% identity), TylCVI in Streptomyces fradiae (46\% identity) and eryBVI in Saccharopolyspora erythraea ( $44 \%$ identity). Alignment of 2,3-dehydratase 
Table 2. Features of ORFs downstream of jadM in the jad cluster of Streptomyces venezuelae

\begin{tabular}{|lcccl|}
\hline ORF十 & $\begin{array}{c}\text { Size of product } \\
(\mathbf{a a}) \neq\end{array}$ & $\begin{array}{c}\text { Distance from precedeing } \\
\text { ORFs }(\mathbf{b p})\end{array}$ & $\begin{array}{c}\text { G+C content } \\
(\mathbf{m o l} \mathbf{\%})\end{array}$ & \multicolumn{1}{c|}{ Putative function } \\
\hline$j a d N$ & 609 & 4 bp overlap with jadM & $70 \cdot 0$ & Acyl-coenzyme A decarboxylase \\
$j a d X$ & 172 & 22 & $72 \cdot 3$ & Not known \\
$j a d O$ & 475 & 1 bp overlap with $j a d X$ & $75 \cdot 9$ & NDP-hexose 2,3-dehydratase \\
$j a d P$ & 376 & 26 & $76 \cdot 8$ & NDP-hexose 3-ketoreductase \\
$j a d Q$ & 269 & 68 & $75 \cdot 1$ & NDP-glucose phosphate nucleotidyltransferase \\
$j a d S$ & 395 & 47 & $75 \cdot 7$ & Glycosyltransferase \\
$j a d T$ & 332 & 32 & $69 \cdot 1$ & NDP-hexose 4,6-dehydratase \\
$j a d U$ & 196 & 8 & $68 \cdot 6$ & NDP-4-keto-6-deoxyhexose 3,5-epimerase \\
$j a d V$ & 341 & 41 & $76 \cdot 5$ & NDP- 4-keto-6-deoxyhexose 4-ketoreductase \\
$j a d R^{*}$ & 204 & $16 \mathbb{S}$ & $73 \cdot 8$ & tetR homologue \\
\hline
\end{tabular}

† Genes are listed in the order that the ORFs occur in the $j a d$ cluster.

‡ The putative start codon for $j a d P$ and $j a d V$ is GTG; for other ORFs it is ATG.

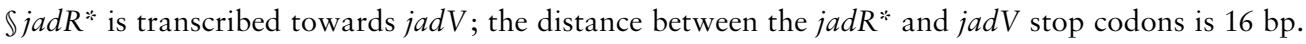

region 1

\begin{tabular}{|c|c|c|}
\hline Lans & 81 & HRSGRFFSVEGLHV \\
\hline UrdS & 77 & HRSGRFFTVEGLHV \\
\hline AveBVI & 80 & HRSGRFFSVEGLHV \\
\hline EryBVI & 94 & HESGRFFSIEGLHV \\
\hline TylCVI & 43 & HESGRFF SIEGLRV \\
\hline Orf10 & 63 & HTSGRFF SIEGLRV \\
\hline MtmV & 82 & HDSGRFFTVEGLRA \\
\hline \multirow[t]{2}{*}{ Jado } & 75 & PPQRPLLHRRGPAR \\
\hline & & . : : : \\
\hline
\end{tabular}

$\begin{array}{lll}\text { LanS } & 408 \text { YEAVHSEEGGR-FLNAESRYLLIE } \\ \text { UrdS } & 407 \text { YEAVHSEEGGR-FLNAESRYLIVD } \\ \text { AVeBVI } & 403 \text { YAAVHSEEGGR-FLHAQARYLFVE } \\ \text { EryBVI } & 443 \text { YDAWHSEEGGR-FYRNENRYMLIE } \\ \text { TYlCVI } & 389 \text { YDTVQSEEGGR-FYHARNRYAIVE } \\ \text { Orf10 } & 409 \text { YDTLQSEEGGR-FHHAENRYVVVE } \\ \text { MtmV } & 430 \text { YDAVQSEEGGR-FYRALSRYLVE } \\ \text { JadO } & 455 \text { YEAVHSEEGGRGFQTPRAATFLG }\end{array}$

region 2

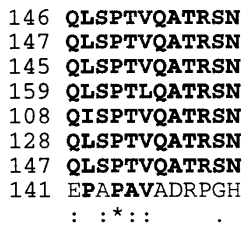

region 4

454 LVRHGHYVNVQARTLLACLNA 453 LVRHGHYVNVQGRTLLACLNA 449 LLRYGRYVNVQARTLLSLLTT 488 LLGHSHYVNIQLRSIIACASA 488 LLGHSHYVNIQLRSIIACASA 440 LLAHGNYVNVELRTLIACAHA 474 LLQHSNYCNIQARSLIACLQS 511 TTRHGHYLNVQARTLLACVHA
Fig. 3. Alignment of the amino acid sequences of JadO with NDP-hexose 2,3dehydratases by CLUSTAL W. Highly conserved amino acids are in bold letters and are marked below the alignment with an asterisk (all aa identical), a colon (all aa similar) or a period (several aa identical). Highly conserved aligned sequences are designated regions $1-4$. Sources of the sequences: LanS, lans in 'Streptomyces cyanogenus'; UrdS, urdS in Streptomyces fradiae; AveBVI, aveBVI in 'Streptomyces avermitilis'; EryBVI, eryBVI in Saccharopolyspora erythraea; TyICVI, tyl-orf6 in Streptomyces fradiae; MtmV, mtmV in 'Streptomyces argillaceus'; Orf10, orf10 in Streptomyces violaceoruber Tü22; JadO, jadO in Streptomyces venezuelae. amino acid sequences omitting JadO showed four highly conserved areas (regions 1-4; bold letters in Fig. 3). When JadO was included in the alignment, sequence conservation was limited to only two of these areas region 3 (HSEEGGRGF at aa 459-468; 87\% identity) and region 4 (HGHYXNVQARTLLA at aa 514-527). The narrower consensus with JadO present presumably reflects divergence of the more substrate-specific JadO enzyme activity. Some 2,3-dehydratases listed in Fig. 3 can participate in the synthesis of two or three different deoxysugars, or of a trideoxyhexose and an aminosugar (Hoffmeister et al., 2000).

jadP. The deduced amino acid sequence of jadP showed appreciable similarity to oxidoreductases in GenBank. The closest match (51\% identical aa) was with an enzyme used in landomycin biosynthesis by 'Streptomyces cyanogenus'; other similar oxidoreductases were Gra-orf26, used by Streptomyces violaceoruber to synthesize the deoxysugar in granaticin, and a gene product of Amycolatopsis mediterranei (45\% identical aa). Related gene products included the 3-ketoreductase
AknQ (43\% identical aa) used during glycosylation of aclarubicin by Streptomyces galilaeus, and dTDP-3,4diketo-2,6-dideoxyglucose 3-ketoreductase (38\% identity) used by Streptomyces antibioticus for C-2 deoxygenation during dTDP-L-oleandrose biosynthesis. Participation of such an oxidoreductase in the biosynthesis of the 2,6-dideoxyhexose in jadomycin B would be consistent with the biosynthetic pathway for other dideoxy sugars proposed by Thorson et al. (1993) and Draeger et al. (1999). This requires a 2,6-dehydratase (e.g. JadO) and an oxidoreductase (e.g. JadP) acting in sequence on NDP-4-keto-6-deoxy-D-glucose to produce 4-keto-2,6-dideoxy-D-glucose as a key intermediate.

jadQ. The product of $j a d Q$ was similar to NDP-glucose synthases in many streptomycetes producing glycosidic metabolites; the strongest resemblance was to TDPglucose synthase of Streptomyces griseus $(75 \%$ identical aa). Other relevant gene products were glucose-1phosphate thymidyltransferase of 'Streptomyces avermitilis' (71\% identical aa), dTDP-1-glucose synthase of Streptomyces galilaeus $(70 \%$ identical aa), $\alpha$-D-glucose- 
1-phosphate thymidylyltransferase of Streptomyces venezuelae ATCC 15439 (67\% identical aa) and glucose1-phosphate thymidylyltransferase of Streptomyces fradiae. The NDP-hexose phosphate transferases consist of four identical subunits, each with a molecular mass of $29 \mathrm{kDa}$ (Thorson et al., 1994); analysis of their sequence shows two conserved regions (Katsube et al., 1991; Liu \& Thorson, 1994; Kirschning et al., 1997). In an alignment of JadQ with NDP-hexose phosphate transferases, these regions could be recognized at two locations. One near the $\mathrm{N}$ terminus was present in all sequences and is associated with activator binding. A more centrally located consensus sequence, present in all transferases except AscA and LanZ2, is believed to bind the substrate. In the AscA sequence, the substrate binds further downstream (Katsube et al., 1991; Thorson et al., 1994) and the difference in binding site is consistent with the different role of AscA in catalysing biosynthesis of a 3,6-rather than a 2,6-dideoxysugar. That pathways to deoxysugars may be initiated with specific sugar phosphates is indicated by the presence in 'Streptomyces cyanogenus' of the two genes, $\operatorname{lan} G$ and $\operatorname{lan} Z 2$, encoding NDP-hexose synthases for the D-olivose and L-rhodinose moieties, respectively, of landomycin (Westrich et al., 1999).

jads. The deduced amino acid sequence of $j a d S$ matched those of many glycosyltransferases. The closest resemblance was to a sugar-flexible elloramycin glycosyltransferase encoded by oleGI (44\% identical aa) and used by Streptomyces olivaceus for biosynthesis of the polyketide-derived antitumour agent elloramycin. The sequence also resembled (35-42\% identical aa) those of glycosyltransferases used in the biosynthesis of nogalamycin by Streptomyces nogalater, the angucycline antibiotics landomycin and urdamycin by Streptomyces fradiae, daunorubicin by Streptomyces peucetius and for transfer of forosamine to the aglycone by Saccharopolyspora spinosa. Genes for glycosyltransferases have been identified in a number of gene clusters for polyketide antibiotic biosynthesis (Baltz \& Seno, 1988; Krugel et al., 1993; Bechthold et al., 1995; Westrich et al., 1999; Trefzer et al., 1999; Kunzel et al., 1999). Where examined, the gene products catalysed specific reactions; thus LanGT1-4 transferred D-olivose and Lrhodinose at different stages during landomycin biosynthesis and UrdGT2 transferred D-olivose, but not Lrhodinose in the urdamycin pathway. In a comparison of the functions and structural features of NDP-sugar glycosyltransferases based on the amino acid sequences of 555 cloned genes, all but two could be assigned to 26 families (Campbell et al., 1997). Using the stereochemistries of substrates and reaction products as criteria, the glycosyltransferases of streptomycete genes such as the $u r d G T 2, d n r S$ and oleG1 were all placed in family 1 , representing a group of enzymes that invert configuration at the reaction site. Since JadS closely resembles UrdGT2, DnrS and OleGI, it probably is a family 1 glycosyltransferase, acting similarly.

jadT. The jadT product showed $68 \%$ sequence identity to the TDP-glucose 4,6-dehydratase used in streptomycin biosynthesis by Streptomyces griseus and 58-69\% identity to NDP-hexose 4,6-dehydratases involved in the biosynthesis of glycosidic components of polyketidederived secondary metabolites (granaticin, landomycin, urdamycin A, erythromycin, avermectin) by 'Streptomyces cyanogenus', Streptomyces fradiae, Streptomyces galilaeus, Streptomyces violaceoruber, Saccharopolyspora erythraea and 'Streptomyces avermitilis'. In actinomycetes, genes for 4,6-dehydratases are more highly conserved than those for glycosyltransferases (Liu \& Thorson, 1994), and fragments of $\operatorname{str} D, E, L$ and $M$ from Streptomyces griseus N2-3-11 have served as effective probes for locating 6-deoxy- or 4,6-dideoxysugar biosynthesis genes (Decker et al., 1996). The phylogenetic tree for protein sequences deduced from the cloned genes or obtained from purified NDPdehydratases indicates that actinomycete 4,6-dehydratase genes are more closely related to each other than to dehydratase genes from species of other orders. The relationship between dehydratases from strains producing natural compounds with similar deoxysugar moieties is even closer, and NDP-glucose 4,6-dehydratase gene probes have proven advantageous in cloning novobiocin and coumermycin $\mathrm{A}(1)$ biosynthesis gene clusters (Steffensky et al., 2000; Wang et al., 2000).

jadU. In a BLASTX search, the product of jadU most closely resembled (61\% identical aa) AknL (dTDP-4keto-6-deoxyhexose 3,5-epimerase,) used in aclacinomycin biosynthesis by Streptomyces galilaeus. It also resembled the putative epimerase (58\% identical aa) used by Streptomyces pencetius to form the daunorubicin precursor thymidine diphospho-L-daunosamine, the NDP-4-keto-6-deoxy-epimerase (58\% identical aa) used by 'Streptomyces avermitilis' for avermectin biosynthesis and the TDP-4-keto-6-deoxyhexose 3,5-epimerase $(56 \%$ identical aa) used by 'Micromonospora megalomicea subsp. nigra' for biosynthesis of the antiparasitic agent megalomicin.

jadV. The product of $j a d V$ showed strong similarity (52\% identical aa) to TDP-4-keto-6-deoxyhexose 4ketoreductase in 'Micromonospora megalomicea subsp. nigra', the putative deoxyhexose reductase ( $49 \%$ identical aa) in Streptomyces griseus, dTDP-4-keto-6-deoxyL-hexose 4-reductase ( $46 \%$ identical aa) in 'Streptomyces avermitilis', the NDP-hexose 4-ketoreductase TylCIV (46\% identical aa) in Streptomyces fradiae and EryBIV $(47 \%$ identical aa) involved in making Lmycarose and D-desosamine in Saccharopolyspora erythraea.

jadR* The deduced amino acid sequence of the $612 \mathrm{bp}$ ORF (jadR*) downstream of $j a d V$, but transcribed in the opposite direction, showed similarity to TetR-family transcriptional regulators in Streptomyces coelicolor A3 (2) (29\% identical aa) and Mycobacterium tuberculosis ( $27 \%$ identical aa), the probable transcription regulator PA1226 in Pseudomonas aeruginosa (29\% identical aa) and the putative TetR regulatory proteins in Prauserella rugosa (31\% identical aa) and Mycobacterium leprae (29\% identical aa). 


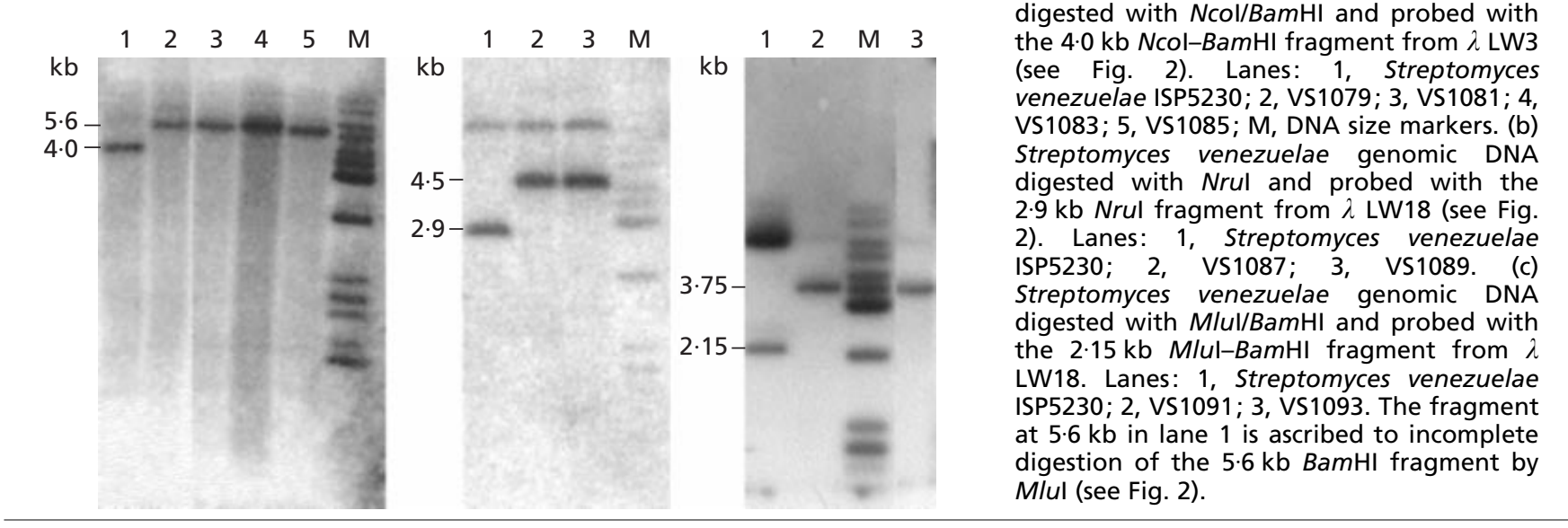

\section{Disruption of jadX, $O, P, Q, S, T, U$ and $V$}

Plasmids containing genes for disruption were linearized at a restriction site near the centre of the insert and ligated with a cassette containing the $\mathrm{Am}^{\mathrm{R}}$ gene from $E$. coli (Chang et al., 2001). Fragments of DNA containing the disrupted gene were recloned in the promiscuous vector pJV326 (He et al., 2001) and the plasmid constructs were transferred from E. coli to Streptomyces venezuelae by intergeneric conjugation (Mazodier et al., 1989). Single colonies of the members of each transconjugant pair, VS1079/1080, VS1081/1082, VS1083/ 1084, VS1085/1086, VS1087/1088, VS1089/1090, VS1091/1092 and VS1093/1094, were isolated. In the first member of each transconjugant pair the $\mathrm{Am}^{\mathrm{R}}$ gene had been inserted in the opposite orientation to the gene disrupted (A series). In the second member of each pair, the two genes were in the same orientation (B series). Probing genomic DNA digests from VS1079, VS1081, VS1083 and VS1085 with the $4.0 \mathrm{~kb}$ NcoI-BamHI fragment from $\lambda \mathrm{LW} 3$ gave a hybridizing band at $4.0 \mathrm{~kb}$ from Streptomyces venezuelae ISP5230 and at $5.6 \mathrm{~kb}$ from the jadXOPQ mutants (Fig. 4a). When genomic DNA from Streptomyces venezuelae ISP5230, VS1087 and VS1089 was probed with the $2.9 \mathrm{~kb} \mathrm{NruI}$ fragment from $\lambda$ LW18 (see Fig. 2), a hybridizing band was located at $2.9 \mathrm{~kb}$ from Streptomyces venezuelae ISP5230 and at $4.5 \mathrm{~kb}$ from strains disrupted in jadS or jadT (Fig. 4b). When the genomic DNA from Streptomyces venezuelae ISP5230, VS1091 and VS1093 was probed with the $2 \cdot 15 \mathrm{~kb} M l u \mathrm{I}-$ Bam HI fragment (see Fig. 2), a hybridizing band at $2.15 \mathrm{~kb}$ was detected from Streptomyces venezuelae ISP5230 and at $3.75 \mathrm{~kb}$ from strains carrying disrupted $j a d U$ or $j a d V$ (Fig. 4c). These are the results expected from double cross-overs disrupting jadX, $O, P$, $Q, S, T, U$ and $V$. Cultures of each of the jad-disrupted transconjugant strains grew normally on MYM agar and in jadomycin-production medium. Analysis of culture extracts by HPLC, and comparison with jadomycin B and jadomycin aglycone standards, showed in all pairs (both A and B series) of insertionally inactivated strains, except those from $j a d X$, a single major peak corresponding to jadomycin aglycone. Extracts showing only the aglycone peak were pooled and the product, purified by flash chromatography on silica gel $\mathrm{H}$, was examined by ${ }^{1} \mathrm{H}$ and ${ }^{13} \mathrm{C}$ NMR spectroscopy. The major signals corresponded in chemical shift values to the resonances in ${ }^{13} \mathrm{C}$ and ${ }^{1} \mathrm{H}$ NMR spectra published for jadomycin aglycone (Ayer et al., 1991). Cultures of jadX-disrupted mutants with the $\mathrm{Am}^{\mathrm{R}}$ gene in each orientation accumulated both jadomycin B and the aglycone; the amounts of each product were similar, but each represented only $10-20 \%$ of the jadomycin B yield in wild-type controls. The results suggest that the $j a d X$ product facilitates accumulation of the glycosylated antibiotic, but is not required for its formation.

\section{Expression from the $\mathrm{Am}^{\mathrm{R}}$ gene promoter}

Since construction of the $\mathrm{Am}^{\mathrm{R}}$ cassette in pJV225 (Chang et al., 2001) from the E. coli plasmid pKC203 (Rao et al., 1983; Kaster et al., 1983) retained the $\mathrm{Am}^{\mathrm{R}}$ gene promoter and omitted a terminator sequence, use of the cassette for insertional inactivation could potentially maintain expression of polycistronically transcribed genes downstream of the insertion site. The promoter activity of the cassette was verified by inserting it upstream of $x y l E$ in the bifunctional promoter probe plasmid pXE4 designed by Ingram et al. (1989). On MYM agar, colonies of Streptomyces venezuelae ISP5230 transformed with pXE4::Am ${ }^{\mathrm{R}}$ (but not controls transformed with pXE4) became bright yellow when sprayed with $0.5 \mathrm{M}$ catechol. Mycelial extracts from shaken cultures of the pXE4 transformants grown in MYM medium averaged 0.7 ( $\pm 0 \cdot 6) \mathrm{mU}$ catechol 2,3dioxygenase activity (mg protein $)^{-1}$, comparable to the 1-6 mU (mg protein $)^{-1}$ reported in Streptomyces lividans and Streptomyces coelicolor A3(2) mycelium carrying pXE4 (Ingram et al., 1989), and contrasting with the $19 \cdot 0( \pm 1 \cdot 2) \mathrm{mU}(\mathrm{mg} \text { protein })^{-1}$ in extracts from 
cultures of pXE4::Am ${ }^{\mathrm{R}}$ transformants. Extracts from cultures of the pXE4::Am ${ }^{\mathrm{R}}$ transformants in Gal2I medium gave $28.6 \mathrm{mU}$ (mg protein) $)^{-1}$. This level of catechol dioxygenase activity implied expression of $x y l E$ from the $\mathrm{Am}^{\mathrm{R}}$ gene promoter.

\section{Complementation of dysfunctional genes by merodiploid construction}

To determine whether failure to produce jadomycin B after insertional inactivation of $j a d S$ was due to the mutation in jadS or to a polar effect preventing expression of downstream genes, a $3.6 \mathrm{~kb} \mathrm{BamHI}$ fragment of DNA from pJV425, containing jadT, $U, V$ and $R^{*}$, was ligated to the $B a m \mathrm{HI}$ end of the $0.6 \mathrm{~kb}$ DNA fragment cloned in pJV424. The $4.2 \mathrm{~kb} \mathrm{NruI-BamHI}$ insert in the resulting plasmid (pJV426) was retrieved by EcoRI/HindIII digestion and recloned in the oriTcontaining bifunctional vector pJV326 to give pJV427. This promiscuous plasmid was transferred conjugally into Streptomyces venezuelae strain VS1087, in which jadS had been inactivated by insertion of the oppositely oriented $\mathrm{Am}^{\mathrm{R}}$ gene. A transconjugant selected for thiostrepton resistance (indicating the presence of free or integrated pJV427) was grown in Gal2I medium under conditions favourable for jadomycin B production, but produced only jadomycin aglycone. The results indicated that introducing the genes downstream of $j a d S$ behind the functional promoter in pJV326 did not restore jadomycin B biosynthesis. This was consistent with the results obtained from disruption of Streptomyces venezuelae with the $\mathrm{Am}^{\mathrm{R}}$ gene cassette in suggesting that inactivation of $j a d S$ per se, rather than a polar effect on expression of downstream genes, was responsible for accumulation of jadomycin aglycone. To confirm that the downstream genes in pJV427 are indeed expressed in thiostrepton-resistant transconjugants, the plasmid was conjugally transferred into strains VS1089, VS1091 and VS1093, in which jadS is intact but jadT, $j a d U$ and $j a d V$, respectively, have been inactivated by insertion of the oppositely oriented $\mathrm{Am}^{\mathrm{R}}$ gene. Selection of thiostrepton-resistant transconjugants and HPLC analysis of extracts from cultures grown in Gal2I medium showed that all three transconjugants produced jadomycin B exclusively, implying complementation of the disrupted genes.

\section{DISCUSSION}

The pathway for biosynthesis of 3,6-dideoxysugars has been firmly established (Liu \& Thorson, 1994) and the enzymes involved have been investigated (Trefzer et al., 1999), but much less is known about the 2,6- and 4,6dideoxygenation pathways that generate the glycosidic components of many secondary metabolites. As in the present investigation, knowledge of biosynthetic reactions is limited to prediction of enzyme functions based on gene sequences, their relationship to the existing database and the phenotypic changes that result from specific gene disruptions. Biochemical characterization of intermediates accumulated after gene inactivation provides supporting evidence for enzyme function and has not only cast light on several sugar biosynthetic pathways, but also helped in the design of hybrid natural compounds (Zhao et al., 1998; Kunzel et al., 1999; Olano et al., 1999).

The absence of the dideoxysugar component from the substance produced when jadO, P,Q, S, T, U and $V$ were disrupted implicates the products of these genes in biosynthesis or attachment of the glycosidic moiety. The conclusion is strengthened by the results from BLAST searches showing marked similarities between the deduced amino acid sequences of the genes disrupted and enzymes for deoxysugar biosynthesis in other species. Based on their sequence homologies, jadO, $P, Q, S, T, U$ and $V$ are assigned to seven biochemical reactions required in Streptomyces venezuelae. The combined evidence from all sources supports a plausible pathway (Fig. 5) for biosynthesis of the jadomycin B sugar. First, $\alpha$-D-glucose 1-phosphate is activated to an NDP-glucose by the jadQ product (NDP-glucose synthase); the activated glucose is then converted to NDP-4-keto-6deoxy-D-glucose by the dehydratase JadT. This irreversible step commits the sugar nucleotide to a pathway in which NDP-4-keto-6-deoxy-D-glucose is a key precusor for 2-deoxysugars and other glycosidic metabolites (Liu \& Thorson, 1994). The subsequent C-2 deoxygenation is catalysed by a pair of enzymes, JadO (a 2,3-dehydratase giving the labile intermediate NDP3,4-diketo-2,6-dideoxyglucose or its 2,3-enol; Draeger et al., 1999) and JadP (an oxidoreductase that reduces the intermediate to NDP-4-keto-2,6-dideoxy-D-glucose). The required epimer of the 2,6-dideoxysugar is probably formed by JadU (NDP-4-keto-2,6-dideoxyhexose epimerase) via an enediol intermediate. Eventually JadV (NDP-4-keto-2,6-dideoxyhexose 4-keto-reductase) reduces the NDP-4-keto-2,6-dideoxyhexose to NDP-Ldigitoxose, and a glycosyltransferase encoded by jadS attaches the activated sugar to jadomycin aglycone.

In the mechanism forming 3,6-dideoxyhexoses in Gramnegative bacteria (Liu \& Thorson, 1994), 5-epimerization (Eep) and 4-reduction (Ered) are involved in the last two steps. The lack of E3 activity (involving an $\operatorname{ascD}$ homologue) in synthesizing the 2,6-dideoxyhexose in daunorubicin and the 2,6- and 4,6-dideoxyhexoses in erythromycin implies that the mechanism generating 2,6- and 4,6-dideoxyhexoses in the Gram-positive streptomycetes differs from that giving 3,6-dideoxyhexoses in Gram-negative bacteria. Genes encoding the NDP-4-keto-6-deoxyhexose 3,5-epimerases and NDP-4keto-6-deoxyhexose 4-ketoreductases have been cloned and sequenced, but the order in which the reactions occur is not known; thus it is uncertain whether NDP2,6-dideoxy-D-threo-4-hexulose or NDP-2,6-dideoxy-Lerythro-4-hexulose is the natural substrate of the $j a d V$ gene product. In the absence of this information, the steps showing 5-epimerization preceding 4-ketoreduction in the route to NDP-L-digitoxose proposed in Fig. 5 are based only on the similarity of JadU and JadV sequences to those of enzymes believed to participate in the pathway for 2,6-dideoxysugar biosynthesis in other 


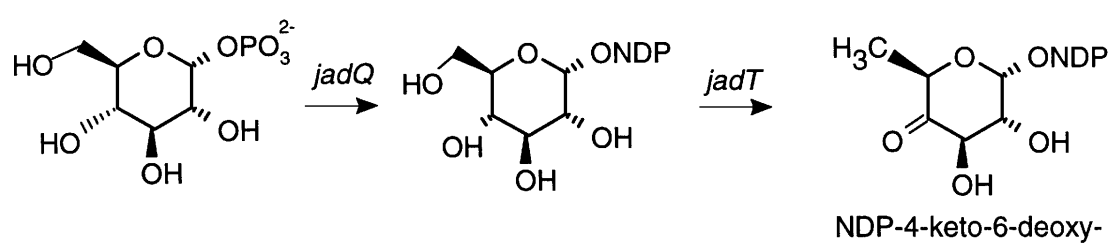

D-glucose

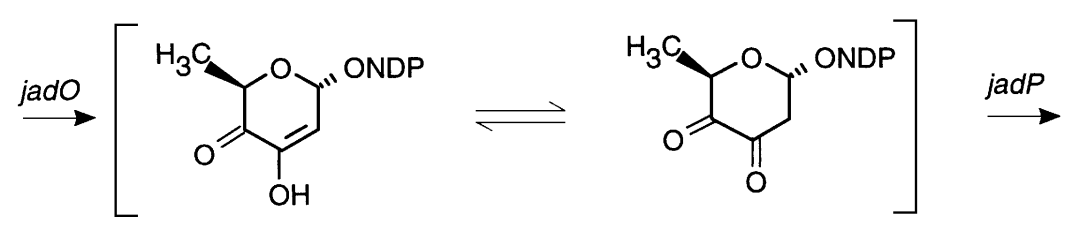

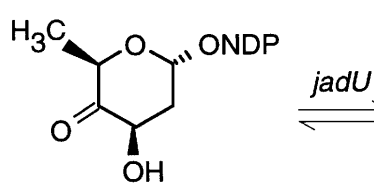

NDP-2,6-dideoxy-Dthreo-4-hexulose

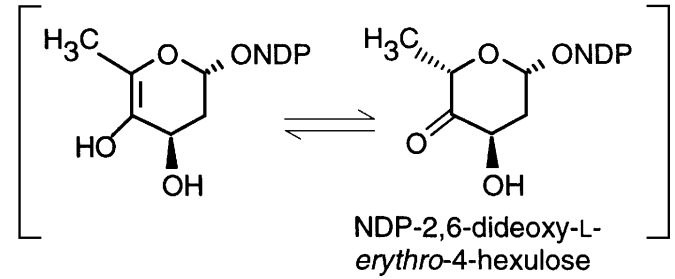

erythro-4-hexulose

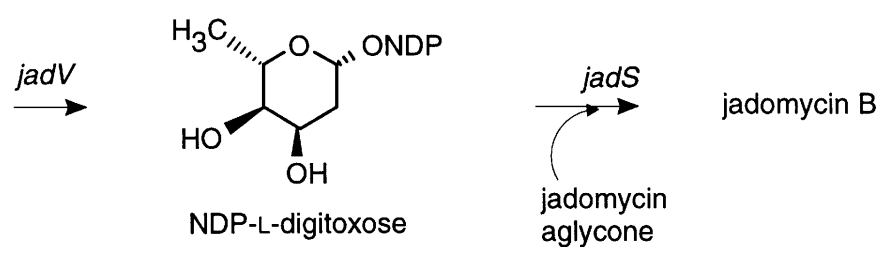

Fig. 5. Proposed pathway for biosynthesis of the L-digitoxose moiety in jadomycin B by Streptomyces venezuelae ISP5230.

bacteria (Thorson et al., 1993; Draeger et al., 1999; Trefzer et al., 1999; Aguirrezabalaga et al., 2000).

Products accumulated by various blocked Streptomyces mutants indicate that post-PKS tailoring by glycosyl transfer can precede other modification steps (Krohn \& Rohr, 1997). Glycosyl transfer may also occur before synthesis of the sugar moiety is completed (Katz \& Donadio, 1993; Madduri et al., 1998). In doxorubicin biosynthesis, the daunosamine moiety may be transferred either to $\varepsilon$-rhodomycinone or to the basic aglycone (aklavinone), six to seven biosynthesis steps before completion of doxorubicin (Bartel et al., 1990; Grimm et al., 1994). In erythromycin biosynthesis, L-mycarose and D-desosamine are transferred sequentially before hydroxylation and $\mathrm{O}$-methylation of the L-mycarose moiety complete the formation of erythromycin A. However, accumulation of jadomycin aglycone as the sole product of strains disrupted at various steps in construction and transfer of the deoxysugar strongly suggest that specific glycosylation by JadS is a necessary final reaction in the jadomycin B biosynthesis pathway. In some other post-assembly reactions modifying poly- ketides, the enzymes for glycosylation do not exhibit absolute specificity (Katz \& Donadio, 1993; Trefzer et al., 1999). Relaxed substrate selection allows glycosyltransferases encoded by the two genes oleI and oleD to play a role in self-resistance during oleandomycin biosynthesis (Quiros et al., 1998). Substrate flexibility for aglycones has also been reported for the glycosyltransferases used by producers of daunorubicin (Madduri et al., 1998), erythromycin (Gaisser et al., 1998) and urdamycin (Hoffmeister et al., 2000). In the methymycin/neomethymycin producer, Zhao et al. (1998) have demonstrated a potential application in genetically engineering hybrid antibiotics by replacing TDP-desosamine with other substrates to create two new macrolide glycosides.

Analysis of gene clusters for biosynthesis of polyketidederived secondary metabolites has usually shown genes for constructing the aglycones to be centrally located and genes regulating transcription to be situated in the upstream region of the cluster. Genes for glycosylation and other post-polyketide modifications may be scattered on both flanks of the core PKS cluster. This 
organization can complicate identification of individual biosynthesis pathways in antibiotics with more than one glycosidic substituent, but was not a factor in the jad cluster of Streptomyces venezuelae ISP5230. The single sugar in the jadomycin B structure and compact clustering of genes for its biosynthesis allow a probable sequence of biosynthetic reactions to be deduced. DDigitoxose is well known as a constituent of plant cardiac (Reichstein \& Weiss, 1962) and other steroidal glycosides (Abe et al., 1994; Abe \& Yamauchi, 2000; Huan et al., 2001; Warashina \& Noro, 2000a, b), and is present in the microbial metabolite ammocidin (Murakami et al., 2001), but L-digitoxose has been previously reported only in bioactive products from actinomycetes. It occurs in the glycosidic components of the macrocyclic antibiotic kijanimicin from Actinomadura kijaniata (Mallams et al., 1981), in the tetrocarcin group of antitumour antibiotics from Micromonospora chalcea (Tomita et al., 1980) and in some antifungal polyene macrolides from streptomycetes (Zielinski et al., 1979).

\section{ACKNOWLEDGEMENTS}

We are grateful to Dr Janet Westpheling, Genetics Department, University of Georgia, for providing the promoter probe vector pXE4. We also thank the Atlantic Region Magnetic Resonance Centre for providing NMR spectra, and Dr H.-w. Liu, Department of Medicinal Chemistry, College of Pharmacy, University of Texas, for advice on the nomenclature of dideoxysugars. This research was supported by the Natural Sciences and Engineering Council of Canada and the Patrick Lett Fund of the Biology Department at Dalhousie University.

\section{REFERENCES}

Abe, F. \& Yamauchi, T. (2000). Pregnane glycosides from the roots of Asclepias tuberosa. Chem Pharm Bull 48, 1017-1022.

Abe, F., Mori, Y., Okabe, H. \& Yamauchi, T. (1994). Steroidal constituents from the roots and stems of Asclepias fruticosa. Chem Pharm Bull 42, 1777-1783.

Aguirrezabalaga, I., Olano, C., Allende, N., Rodriguez, L., Brana, A. F., Mendez, C. \& Salas, J.A. (2000). Identification and expression of genes involved in biosynthesis of oleandrose and its intermediate L-olivose in the oleandomycin producer Streptomyces antibioticus. Antimicrob Agents Chemother 44, 1266-1275.

Ayer, S. W., McInnes, A. G., Thibault, P., Walter, J. A., Doull, J. L., Parnell, T. \& Vining, L. C. (1991). Jadomycin, a novel $8 H$ benz $[b]$ oxazolo[3,2- $f]$ phenanthridine antibiotic from Streptomyces venezuelae ISP5230. Tetrahedron Lett 32, 6301-6304.

Baltz, R. H. \& Seno, E. T. (1988). Genetics of Streptomyces fradiae and tylosin biosynthesis. Annu Rev Microbiol 42, 547-574.

Bartel, P. L., Connors, N. C. \& Stroll, W. R. (1990). Biosynthesis of anthracyclines: analysis of mutants of Streptomyces sp. strain C5 blocked in daunomycin biosynthesis. J Gen Microbiol 136, 1877-1881.

Bechthold, A., Sohng, J. K., Smith, T. M., Chu, X. \& Floss, H. G. (1995). Identification of Streptomyces violaceoruber Tü22 genes involved in the biosynthesis of granaticin. Mol Gen Genet 248, 610-620.
Campbell, J. A., Davies, G. J., Bulone, V. \& Henrissat, B. (1997). A classification of nucleotide-diphospho-sugar glycosyltransferases based on amino acid sequence similarities. Biochem $J$ 326, 929-939.

Chang, Z., Sun, Y., He, J. \& Vining, L. C. (2001). p-Aminobenzoic acid and chloramphenicol biosynthesis in Streptomyces venezuelae: gene sets for a key enzyme, 4-amino-4-deoxychorismate synthase. Microbiology 147, 2113-2126.

Crowell, K. G. (1993). Biosynthesis of jadomycin. BSc Honours Thesis, Acadia University, Canada.

David, E. C., Christopher, T. W. \& Khosla, C. (1998). Harnessing the biosynthetic code: combinations, permutations, and mutations. Science 282, 63-68.

Decker, H., Gaisser, S., Pelzer, S., Schneider, P., Westrich, L., Wohlleben, W. \& Bechthold, A. (1996). A general approach for cloning and characterization of dNDP-glucose dehydratase genes from actinomycetes. FEMS Microbiol Lett 141, 195-201.

Doull, J. L., Ayer, S. W., Singh, A. K. \& Thibault, P. (1993). Production of a novel polyketide antibiotic, jadomycin B, by Streptomyces venezuelae following heat shock. J Antibiot 46, 849-871.

Draeger, G., Park, S.-H. \& Floss, H. G. (1999). Mechanism of the 2deoxygenation step in the biosynthesis of the deoxyhexose moieties of the antibiotics granaticin and oleandomycin. J Am Chem Soc 121, 2611-2612.

Facey, S. (1994). Cloning, sequencing and expression of a bromoperoxidase-catalase gene from Streptomyces venezuelae. $\mathrm{PhD}$ thesis, Hohenheim University, Germany.

Flett, F., Mersinias, V. \& Smith, C. P. (1997). High efficiency intergeneric conjugal transfer of plasmid DNA from Escherichia coli to methylDNA-restricting streptomycetes. FEMS Microbiol Lett 155, 223-229.

Gaisser, S., Bohm, G. A., Doumith, M., Raynal, M. C., Dhillon, N., Corres, J. \& Leadlay, P. F. (1998). Analysis of eryBI, eryBIII and eryBVII from the erythromycin biosynthetic gene cluster in Saccharopolyspora erythraea. Mol Gen Genet 258, 78-88.

Gaisser, S., Reather, J., Wirtz, G., Kellenberger, L., Staunton, J. \& Leadlay, P. F. (2000). A defined system for hybrid macrolide biosynthesis in Saccharopolyspora erythraea. Mol Microbiol 36, 391-401.

Grimm, A., Madduri, K., Ali, A. \& Hutchinson, C. R. (1994). Characterization of the Streptomyces peucetius ATCC 29050 genes encoding doxorubicin polyketide synthase. Gene 151, 1-8.

Han, L., Yang, K., Ramalingam, E., Mosher, R. H. \& Vining, L. C. (1994). Cloning and characterization of polyketide synthase genes for jadomycin B biosynthesis in Streptomyces venezuelae ISP5230. Microbiology 140, 3379-3389.

He, J., Magarvey, N., Piraee, M. \& Vining, L. C. (2001). The gene cluster for chloramphenicol biosynthesis in Streptomyces venezuelae ISP5230 includes novel shikimate pathway homologues and a monomodular nonribosomal peptide synthetase gene. Microbiology 147, 2817-2829.

Hoffmeister, D., Ichinose, K., Domann, S. \& 9 other authors (2000). The NDP-sugar co-substrate concentration and the enzyme expression level influence the substrate specificity of glycosyltransferases: cloning and characterization of deoxysugar biosynthetic genes of the urdamycin biosynthetic gene cluster. Chem Biol 7, 821-831.

Hopwood, D. A. \& Sherman, D. H. (1990). Molecular genetics of polyketides and its comparison to fatty acid biosynthesis. Annu Rev Genet 24, 37-66.

Hopwood, D. A., Bibb, M. J., Chater, K. F., Kieser, T., Bruton, C. J., 
Kieser, H. M., Lydiate, D. J., Smith, C. P., Ward, J. M. \& Schrempf, H. (1985). Genetic Manipulation of Streptomyces: a Laboratory Manual. Norwich: John Innes Foundation.

Huan, V. D., Ohtani, K., Kasai, R., Yamasaki, K. \& Tuu, N. V. (2001). Sweet pregnane glycosides from Telosma procumbens. Chem Pharm Bull 49, 453-460.

Hutchinson, C. R. (1999). Microbial polyketide synthases: more and more prolific. Proc Natl Acad Sci U S A 96, 3336-3338.

Ingram, C., Brawner, M., Youngman, P. \& Westpheling, J. (1989). $x y l E$ functions as an efficient reporter gene in Streptomyces spp.: use for the study of galP1, a catabolite-controlled promoter. J Bacteriol 171, 6617-6624.

Ishikawa, J. \& Hotta, K. (1999). FramePlot: a new implementation of the Frame analysis for predicting protein-coding regions in bacterial DNA with a high $\mathrm{G}+\mathrm{C}$ content. FEMS Microbiol Lett 174, 252-253.

Katsube, T., Kazuta, Y., Tanizawa, K. \& Fukui, T. (1991). Expression in Escherichia coli of UDP-glucose pyrophosphorylase cDNA from potato tuber and functional assessment of the five lysyl residues located at the substrate-binding site. Biochemistry 30, 8546-8551.

Kaster, K. R., Burgett, S. G., Nagarajah, R. R. \& Ingolia, T. D. (1983). Analysis of a bacterial hygromycin B resistance gene by transcriptional and translational fusions and by DNA sequencing. Nucleic Acids Res 11, 6895-6911.

Katz, L. \& Donadio, S. (1993). Polyketide synthesis: prospects for hybrid antibiotics. Annu Rev Microbiol 47, 875-912.

Kieser, T., Bibb, M. J., Buttner, M. J., Chater, K. F. \& Hopwood, D. A. (2000). Practical Streptomyces Genetics. Norwich: John Innes Foundation.

Kirschning, A., Bechthold, A. \& Rohr, J. (1997). Chemical and biochemical aspects of deoxysugars and deoxyoligosaccharides. Topics Curr Chem 188, 1-84.

Krohn, K. \& Rohr, J. (1997). Angucyclines: total syntheses, new structures, and biosynthetic studies of an emerging new class of antibiotics. Topics Curr Chem 188, 127-195.

Krugel, H., Schumann, G., Hanel, F. \& Fiedler, G. (1993). Nucleotide sequence analysis of five putative Streptomyces griseus genes, one of which complements an early function in daunorubicin biosynthesis that is linked to a putative gene cluster involved in TDP-daunosamine formation. Mol Gen Genet 241, 193-202.

Kulowski, K., Wendt-Pienkowski, E., Han, L., Yang, K., Vining, L. C. \& Hutchinson, C. R. (1999). Functional characterization of the jadI gene as a cyclase forming angucyclinones. I Am Chem Soc 121, 1786-1794.

Kunzel, E., Faust, B., Oelkers, C., Weissbach, U., Bearden, D. W., Weitnauer, G., Westrich, L., Bechthold, A. \& Rohr, J. (1999). Inactivation of the urdGT2 gene, which encodes a glycosyltransferase responsible for the C-glycosyltransfer of activated D-olivose, leads to formation of the novel urdamycins I, J, and K. J Am Chem Soc 121, 11058-11062.

Larson, J. L. \& Hershberger, C. L. (1986). The minimal replicon of a streptomycete plasmid produces an ultrahigh level of plasmid DNA. Plasmid 15, 199-209.

Liu, H.-w. \& Thorson, J. S. (1994). Pathways and mechanisms in the biosynthesis of novel deoxysugars by bacteria. Annu Rev Microbiol 48, 223-256.

MacNeil, D. J., Gewain, K. M., Rudy, C. L., Dezeny, G., Gibbons, P. H. \& MacNeil, T. (1992). Analysis of Streptomyces avermitilis genes required for avermectin biosynthesis utilizing a novel integration vector. Gene 111, 61-68.
Madduri, K., Kennedy, J., Rivola, G. \& 8 other authors (1998). Production of the antitumour drug epirubicin (4'-epidoxorubicin) and its precursor by a genetically engineered strain of Streptomyces peucetius. Nat Biotechnol 16, 69-74.

Mallams, A. K., Puar, M. S. \& Rossman, R. R. (1981). Kijanimicin. 1. Structure of the individual sugar components. J Am Chem Soc 103, 3938-3940.

Mazodier, P., Peter, R. \& Thompson, C. (1989). Intergeneric conjugation between Escherichia coli and Streptomyces species. J Bacteriol 171, 3583-3585.

McDaniel, R., Thamchaipenet, A., Gustafsson, C., Fu, H., Betlach, M. \& Ashley, G. (1999). Multiple genetic modifications of the erythromycin polyketide synthase to produce a library of novel 'unnatural' natural products. Proc Natl Acad Sci USA 96, 1846-1851.

Murakami, R., Tomikawa, T., Shin-Ya, K., Shinozaki, J., Kajiura, T., Seto, H. \& Hayakawa, Y. (2001). Ammocidin, a new apoptosis inducer in Ras-dependent cells from Saccharothrix sp. II. Physicochemical properties and structure elucidation. J Antibiot 54, 714-717.

Olano, C., Lomovskaya, N., Fonstein, L., Roll, J. T. \& Hutchinson, C. R. (1999). A two-plasmid system for the glycosylation of polyketide antibiotics : bioconversion of epsilon-rhodomycinone to rhodomycin D. Chem Biol 6, 845-855.

Quiros, L. M., Aguirrezabalaga, I., Olano, C., Mendez, C. \& Salas, J. A. (1998). Two glycosyltransferases and a glycosidase are involved in oleandomycin modification during its biosynthesis by Streptomyces antibioticus. Mol Microbiol 28, 1177-1185.

Rao, R. N., Allen, N. E., Hobbs, J. N., Jr, Alborn, W. E., Jr, Kirst, H. A. \& Paschal, J. W. (1983). Genetic and enzymatic basis for hygromycin B resistance in E. coli. Antimicrob Agents Chemother 24, 689-695.

Reichstein, T. \& Weiss, E. (1962). The sugars of the cardiac glycosides. Adv Carbohydr Chem 17, 65-120.

Sambrook, J., Fritsch, E. F. \& Maniatis, T. (1989). Molecular Cloning: a Laboratory Manual, 2nd edn. Cold Spring Harbor, NY : Cold Spring Harbor Laboratory.

Shen, Y., Yoon, P., Yu, T.-w., Floss, H. G., Hopwood, D. A. \& Moore, B.S. (1999). Ectopic expression of the minimal whiE polyketide synthase generates a library of aromatic polyketides of diverse sizes and shapes. Proc Natl Acad Sci U S A 96, 3622-3627.

Steffensky, M., Muhlenweg, A., Wang, Z., Li, A. \& Heide, L. (2000). Identification of the novobiocin biosynthesis gene cluster of Streptomyces sphaeroides NCIB 11891. Antimicrob Agents Chemother 44, 1214-1222.

Stuttard, C. (1982). Temperate phages of Streptomyces venezuelae: lysogeny and host specificity shown by SV1 and SV2. J Gen Microbiol 128, 115-121.

Thompson, J. D., Higgins, D. G. \& Gibson, T. J. (1994). CLUSTAL W : improving the sensitivity of progressive multiple sequence alignment through sequence weighting, position-specific gap penalties and weight matrix choice. Nucleic Acids Res 22, 4673-4680.

Thorson, J. S., Lo, S. F. \& Liu, H.-w. (1993). Biosynthesis of 3,6dideoxyhexoses: new mechanistic reflections upon 2,6-dideoxy, 4,6-dideoxy, and amino sugar construction. J Am Chem Soc 115, 6993-6994.

Thorson, J. S., Lo, S. F., Ploux, O., He, X. \& Liu, H.-w. (1994). Studies of the biosynthesis of 3,6-dideoxyhexose: molecular cloning and characterization of the asc (ascarylose) region from Yersinia pseudotuberculosis serogroup VA. J Bacteriol 176, 5483-5493.

Tomita, F., Tamaoki, T., Shirahata, K., Kasai, M., Morimoto, M., 
Ohkubo, S., Mineura, K. \& Ishii, S. (1980). Novel antitumor antibiotics, tetrocarcins. J Antibiot 33, 668-670.

Trefzer, A., Salas, J. A. \& Bechthold, A. (1999). Genes and enzymes involved in deoxysugar biosynthesis in bacteria. Nat Prod Rep 16, 283-299.

Walker, S., Valentine, K. G. \& Kahne, D. (1990). Sugar as DNA binders: a comment on the calicheamicin oligosaccharide. J Am Chem Soc 112, 6428-6429.

Wang, Z., Li, S. \& Heide, L. (2000). Identification of the coumermycin A1 biosynthesis gene cluster of Streptomyces rishiriensis DSM 40489. Antimicrob Agents Chemother 44, 3040-3048.

Wang, L., McVey, J. \& Vining, L. C. (2001). Cloning and functional analysis of a phosphopantetheinyl transferase superfamily gene associated with jadomycin biosynthesis in Streptomyces venezuelae ISP5230. Microbiology 147, 1535-1545.

Warashina, T. \& Noro, T. (2000a). Steroidal glycosides from the aerial part of Asclepias incarnata L. II. Chem Pharm Bull 48, 99-107.

Warashina, T. \& Noro, T. (2000b). Cardenolide and oxypregnane glycosides from the root of Asclepias incarnata L. Chem Pharm Bull 48, 516-524.

Westrich, L., Domann, S., Faust, B., Bedford, D., Hopwood, D. A.
\& Bechthold, A. (1999). Cloning and characterization of a gene cluster from Streptomyces cyanogenus S136 probably involved in landomycin biosynthesis. FEMS Microbiol Lett 170, 381-387.

Yang, K., Han, L., Ayer, S. W. \& Vining, L. C. (1996). Accumulation of the angucycline antibiotic rabelomycin after disruption of an oxygenase gene in the jadomycin B biosynthetic gene cluster of Streptomyces venezuelae. Microbiology 142, 123-132.

Zhao, L., Sherman, D. H. \& Liu, H.-w. (1998). Biosynthesis of desosamine: construction of a new methymycin/neomethymycin analogue by deletion of a desosamine biosynthetic gene. J Am Chem Soc 120, 10256-10257.

Zielinski, J., Jereczek, E., Sowinski, P., Falkowski, L., Rudowski, A. \& Borowski, E. (1979). The structure of a novel sugar component of polyene macrolide antibiotics: 2,6-dideoxy-L-ribohexopyranose. J Antibiot 32, 565-568.

Zukowski, M. M., Gaffney, D. F., Speck, D., Kauffmann, M., Findeli, A., Wisecup, A. \& Lecocq, J. (1983). Chromogenic identification of genetic regulatory signals in Bacillus subtilis based on expression of a cloned Pseudomonas gene. Proc Natl Acad Sci US A 80, 1101-1105.

Received 16 October 2001; accepted 10 January 2002 